\title{
Vitamin A, endocrine tissues and hormones: interplay and interactions
}

\author{
J Brossaud1,2,3, V Pallet 1,3 and J-B Corcuff',2,3 \\ ${ }^{1}$ Université de Bordeaux, Nutrition et Neurobiologie Intégrée, Bordeaux, France \\ ${ }^{2}$ Department of Nuclear Medicine, CHU de Bordeaux, Pessac, France \\ 3INRA, Nutrition et Neurobiologie Intégrée, UMR1286, Bordeaux, France
}

\begin{abstract}
Vitamin A (retinol) is a micronutrient critical for cell proliferation and differentiation. In adults, vitamin A and metabolites such as retinoic acid (RA) play major roles in vision, immune and brain functions and tissue remodelling and metabolism. This review presents the physiological interactions of retinoids and endocrine tissues and hormonal systems. Two endocrine systems have been particularly studied. In the pituitary, retinoids target the corticotrophs with a possible therapeutic use in corticotropinomas. In the thyroid, retinoids interfere with iodine metabolism and vitamin A deficiency aggravates thyroid dysfunction caused by iodine-deficient diets. Retinoids use in thyroid cancer appears less promising than expected. Recent and still controversial studies investigated the relations between retinoids and metabolic syndrome. Indeed, retinoids contribute to pancreatic development and modify fat and glucose metabolism. However, more detailed studies are needed before planning any therapeutic use. Finally, retinoids probably play more minor roles in adrenal and gonads development and function apart from their major effects on spermatogenesis.
\end{abstract}

\author{
Correspondence \\ should be addressed \\ to J B Corcuff \\ Email \\ jean-benoit.corcuff@ \\ chu-bordeaux.fr
}

\section{Introduction}

Vitamin A (retinol) is a lipophilic micronutrient that is critical for embryo and child development $(1,2)$. In adults, vitamin $\mathrm{A}$ and metabolites (mainly retinoic acid) are critical for the control of cell proliferation and differentiation, and for the maintenance of some very specific cell functions such as photo-transduction. Vitamin A deficiency is a marker of malnutrition that correlates with infection and mortality in children and possibly in childbearing women. Vitamin A is present in foods of animal origin such as liver, eggs and dairy products. An alternative source of vitamin A is the absorption of provitamin A - carotenoids - from plants. However, although carotenoids are abundant, their absorption is about one order of magnitude less efficient compared to vitamin A. Thus, in populations from low-income countries, to depend solely on vegetable intakes for vitamin A sources increases the risk of vitamin A deficiency. The latter causes anomalies of development such as childhood blindness as vitamin $\mathrm{A}$ and metabolites act as morphogens that modulates gene transcription during embryogenesis. In developed adults, vitamin A and metabolites play key roles in vision, immune and brain functions and tissue remodelling and metabolism.

To paraphrase Shearer and coworkers (3): is vitamin A a vitamin for the glands? To endocrinologists, vitamin A presents some similarities to vitamin D: it is a necessary lipophilic nutrient, it is transported by carrier proteins in the blood, it may be metabolised in the organism according to its needs, and it acts on nuclear receptors to modify gene transcription. Conversely, it is not regulated by a specific endocrine system (such as the calciumPTH duet for vitamin D) and thus less known by the http://www.endocrineconnections.org DOI: 10.1530/EC-17-0101
() 2017 The authors Published by Bioscientifica Ltd
This work is licensed under a Creative Commons Attribution-NonCommercial-NoDerivatives 4.0 International License. 
endocrinologist community than vitamin D. This review will present the known physiological interactions of vitamin A and endocrine tissues and hormonal systems in normal adults with minor incursions in childhood or pathology when appropriate. When available, we cited reviews; we thus apologize not to be able to cite multiple pertinent references as space is constrained.

\section{Brief physiology of the retinoids}

\section{Natural retinoids absorption}

Retinoids constitute the family of molecules that includes both naturally occurring compounds with vitamin A activity as well as synthetic analogues of retinol or retinoic acid. Some of the latter are clinically used. Vitamin A in the body derives from the diet either of animal sources (all-trans retinol or retinyl esters) or plants sources (carotenoids). A simplified view of natural retinoids metabolism is presented here but detailed reviews can be found $(4,5,6)$. To summarise, retinol, retinyl esters and carotenoids absorption depends both on common lipid absorption and on specific enzymes, binding proteins and transporters $(4,5,7)$. Retinol is directly taken up by enterocytes, whereas retinyl esters must be hydrolysed by extracellular retinyl ester hydrolases (REH) within the lumen (8). Retinoids are hydrophobic and thus are usually bound in the cells to specific retinoid-binding proteins. For instance, cellular retinol-binding protein Type II (CRBPII) is expressed in the intestinal mucosa to facilitate retinol and retinal uptake and enterocyte storage (6). In enterocytes, retinol is esterified with long-chain fatty acids by lecithin:retinol acyltransferases to retinyl esters that are delivered via chylomicrons to hepatocytes that thus uptake about $70 \%$ of dietary retinol $(4,5,9)$. Retinyl esters are hydrolysed in hepatocytes and transferred - possibly via cellular retinol-binding protein (RBP) Type I - for re-esterification and storage into hepatic stellate cells $(4,5$, 10). Via yet unknown sensing mechanisms when retinol is needed in other tissues, the stellate cells hydrolyse retinyl esters. Retinol is then back-transferred to hepatocytes and liberated along with retinol-binding protein (RBP). In plasma, retinol and RBP form a ternary complex with transthyretin that may also transport thyroxin to tissues (11). These non-hepatic tissues may also incorporate the ingested retinol not uptaken by hepatocytes (about 30\%).

Carotenoids may be imported through a scavenger receptor, gatekeeper of their absorption as its expression is controlled by vitamin A metabolites (12). They are subsequently enzymatically converted to retinoid or incorporated unmodified into chylomicrons. Although abundant in food, the amount of retinol originating from carotenoids is limited: the conversion of $12 \mu \mathrm{g}$ betacarotene generates about $1 \mu \mathrm{g}$ vitamin A (9).

Thus, the delivery of retinoids to the non-hepatic cells depends on the temporal distance from the previous meal: in fasting-state cells are mainly delivered retinol bound to RBP and transthyretin, in post-prandial state retinyl esters are mainly delivered by lipoproteins.

\section{Retinoids cellular effects}

In tissues, retinol cellular uptake can depend on passive diffusion. In cells that have high needs of retinol uptake is usually facilitated by a RBP transporter, STRA6 (STimulated by Retinoic Acid 6) (13) (Fig. 1). STRA6 can also facilitate retinol efflux. Mutations of this protein cause severe and often lethal development abnormalities (14). Within cells, retinol is metabolised and most of its functions are in fact exerted by its metabolites. The intracellular concentrations of these retinoids are controlled by the activities of several metabolic enzymes. The expression and activity of the latter vary among cell types and differentiation. Partially redundant dehydrogenases metabolise all-trans retinol in all-trans retinaldehyde and the latter in all-trans retinoic acid (atRA) by retinaldehyde dehydrogenases (RALDH) (Fig. 1) (4). atRA is degraded by hydroxylation by cytochrome P450 enzymes mainly by CYP26A1, a RA-induced p450 enzyme (15). Mutations of this enzyme are possibly a cause of sirenomelia through RA excessive signalling at the caudal end of the embryo (16). Various isomers of RA exist. The major one is atRA (tretinoin); a minor one is 13-cis RA (isotretinoin) and a possible one is 9-cis RA (alitretinoin). There is however no large body of evidence of the natural occurrence of 9-cis RA, a potent RXR agonist. To assay sub-picomolar amounts of RA isomers is indeed technically challenging and 9-cis RA is yet to be found in tissues other than the pancreas (17). Thus, it is difficult to be precise about the relative concentrations of these isomers in given tissues. Indeed, it seems that different equilibria occur as a function of 'isomerisation chaperones' such as glutathione S-transferase that can act as isomerases (18). Finally, the retinol metabolite 11-cis-retinal is essential for photo-transduction in the retina (19).

The physiological actions of atRA are mediated primarily by its binding to RA receptors (RAR $\alpha, \beta$ and $\gamma$ isoforms) and subsequent formation of heterodimers of 


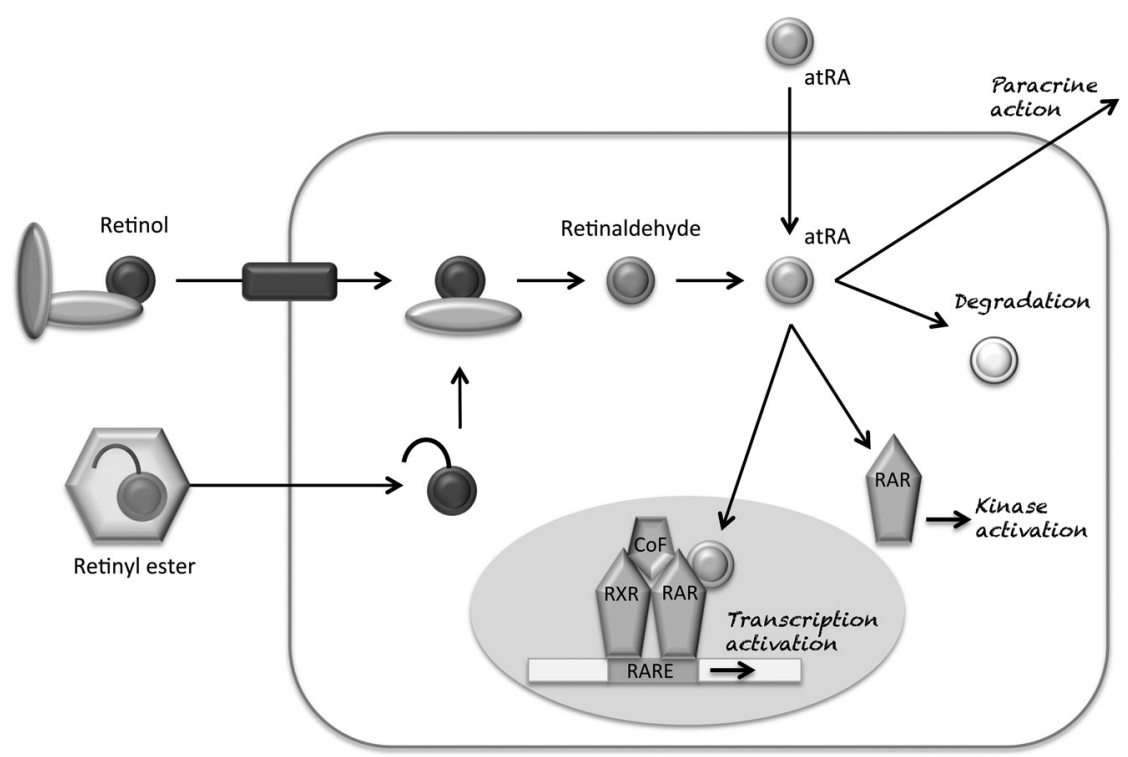

Figure 1

Retinol bound in the plasma to retinol-binding protein (RBP) and transthyretin is uptaken by an RBP-binding transporter, STRA6. Retinyl esters enter the cells associated with chylomicrons (4) to be transformed into retinol by retinyl ester hydrolase. This step can be reversed by lecithin:retinol acyltransferase (2). All-trans retinol is metabolised by retinol dehydrogenases (3) into all-trans retinaldehyde. This step can be reversed by retinal reductase (4). All-trans retinaldehyde is metabolised into all-trans retinoic acid (atRA) by retinaldehyde dehydrogenase (5). atRA is degraded by oxidation/catabolised by cytochrome P450 enzymes (mainly CYP26A1) (6). atRA actions are mediated primarily by RA receptors via heterodimers of retinoic acid receptor (RAR) and retinoic $X$ receptors (RXR) acting with cofactors (COF) on RA response elements (RAREs) of target genes. In the absence of retinoid ligand, RAR/RXR heterodimers are bound to transcriptional repressors. Upon retinoid ligand binding, the heterodimers are bound to coactivator proteins. atRA may also exert non-genomic effects through cytoplasmic kinases $(20,22)$
RAR and retinoic $\mathrm{X}$ receptors ( $\mathrm{RXR} \alpha, \beta$ and $\gamma$ isoforms) (20). RAR and RXR are members of the large family of hormones, vitamins and lipid receptors: receptors for steroids, thyroid hormones, vitamin $\mathrm{D}$ and peroxisome proliferator-activated receptors (PPAR). They act as liganddependent transcription factors. RAR and RXR form heterodimers that regulate the transcriptional activation on the RA response elements (RAREs) of retinoids target genes. Most tissues are targets of retinoids through different heterodimeric complexes. There is apparently a large degree of functional redundancy between the various heterodimers of $\operatorname{RAR} \alpha, \beta$ and $\gamma$ and $\operatorname{RXR} \alpha, \beta$ and $\gamma$. Interestingly, in the absence of retinoid ligand, $\mathrm{RAR} / \mathrm{RXR}$ heterodimers act as transcriptional repressors via a corepressor complex that includes $\mathrm{N}$-CoR1 or N-CoR2 (SMRT, Silencing Mediator of Retinoic acid and Thyroid hormone receptors) and proteins with histone deacetylase activity. Upon retinoid ligand binding, the RAR/RXR heterodimers modify their structure and interact with a higher affinity with coactivator proteins that include SRC 1, 2 and 3 and proteins with histone acetyltransferase activity such as p300 $(2,20)$. Of note, Dax1 (NR0B1) a critical developmental transcription factor in steroidogenic tissues has initially been described as a competitor of RAR/RXR heterodimers on the RAREs (21).

RA action through so-called nuclear receptors may not be limited to RAR-induced transcriptional effects. Firstly, RA could act on RXR receptors through one of its metabolite: 9-cis RA. However, although 9-cis RA is a powerful agonist of RXR, extensive proof of its presence within cells is lacking apart from few publications (17). Secondly, RA may exert non-genomic effects through receptors present in the cytosol or in membranes (20). Indeed, RA can rapidly modulate MAP kinases, phosphatidylinositol 3-kinase, calmodulin-dependent kinases, etc $(20,22)$. This could establish crosstalks between kinase cascades and RAR-activated genomic pathways leading to coordinated phosphorylations targeting RAR themselves, other receptors, coregulators and histones $(20,23)$.

In conclusion, vitamin A metabolites act as intracellular ligands on identified receptors and other cellular targets. Unknown or controversial steps persist such as: what are the sensor mechanisms promoting the liberation of stocks of retinol from the liver, are the oxidised metabolites of RA really inactive, are there mechanisms specifically responsible of isomerisation of RA, are there specific cellular actions of the RA isomers, are there hormonal controls of RA signalling, etc?

Keeping these interrogations in mind, we will present the known interactions of vitamin A and metabolites with endocrine tissues and hormones action.

\section{Vitamin A and the hypothalamo-pituitary- peripheral gland axes}

There are arguments for a role of retinoids in the development and function of the hypothalamus, the 
pituitary and the peripheral glands they act upon. Indeed, in these tissues, there are RAR and RARE-bearing genes $(24,25,26,27)$ and retinoids-metabolising enzymes $(28,29,30)$. In vivo studies also show modifications of hypothalamo-pituitary-peripheral gland axes upon retinoid deprivation or treatment $(31,32,33,34,35,36)$.

\section{Vitamin A and the hypothalamo-pituitary-thyroid axis}

RA does not seem to be involved in thyroid organogenesis (37). Conversely, RA appears involved in maintaining a developed thyroid cell phenotype both in animals and humans. In animals, vitamin A deficiency causes thyroid hypertrophy with a reduction of iodine uptake, of thyroglobulin and of thyroid hormones synthesis ((38) and older publications within). Combined iodine and vitamin A-deficient diets produce greater impairments in thyroid metabolism than either isolated iodine or vitamin A-deficient diets. In children with moderate vitamin A deficiency, TSH concentrations, thyroid volume and total T4 are increased (38). A very important point about vitamin A and thyroid metabolism is the possible co-existence of iodine and vitamin A deficiencies because of their high prevalence in developing countries: more than $30 \%$ children had simultaneous vitamin A deficiency and goitre in Côte d'Ivoire (32). There are interactions between vitamin $\mathrm{A}$ and iodine metabolism as indicated by observational and interventional studies. In iodidedeficient children, vitamin A increases TSH stimulation and thyroid size but reduces risk of hypothyroidism $(31,33)$. In these children, vitamin A supplementation improves iodide efficiency $(31,32)$.

Thus, various works investigated the actions of RA on thyrocytes (mainly expression and function of key proteins). Retinyl palmitate administration decreases thyroid gland size and serum thyroid hormones and conversely increases thyroidal iodine uptake and hepatic conversion of T4 to T3 in rats (39). Interestingly, a low dose of atRA decreased iodine uptake, whereas the same dose of 13-cis RA increased iodine uptake (29). RA isoforms may thus have different consequences on thyrocyte functions. TSH-induced thyroid hormones synthesis requires the incorporation of iodide into the thyrocytes via the sodium-iodide symporter (NIS), its transport through the cell with pendrin to thyroglobulin (Tg) in the lumen. Iodide oxidation and organification are catalysed by thyroperoxidase (TPO) with $\mathrm{H}_{2} \mathrm{O}_{2}$ produced by a dual oxidase. Various steps in this process depend on RA with noticeable differences related to the different cell models used complicating the description of the physiological role of RA. RA reduces TSH receptor mRNA levels (40). The dual oxidase is upregulated in animal treated by an isomer of RA, 13-cis RA, but downregulated by atRA (29). As 13-cis RA does not bind efficiently to RAR or RXR, this suggests either different cellular targets for these two retinoids or a critical role for the inter isomer conversion. RA may suppress the accumulation of TPO and Tg mRNA stimulated by TSH in a time- and dose-dependent manner in cultures of human thyrocytes $(41,42)$.

The main recent reason for the interest about the role of RA in the thyroid is probably its potential therapeutic use in thyroid cancer. The rational for this interest is precisely the potential ability of RA isoforms to sustain cell differentiation or to reverse cell dedifferentiation in various models of cancer. With regards to a potential use to eradicate cancer cells with 131I, NIS was particularly investigated. In rat follicular cell lines, RA increases NIS mRNA levels and iodide uptake, but this effect was not seen in untransformed cells $(43,44)$. More importantly, an increase of iodide uptake was described in human thyroid cancer $(43,44)$. Thus, the use of RA in thyroid through the increased expression of NIS to increase 131I uptake has been under careful investigation in human cancers $(45,46,47,48)$. Unfortunately, different studies did not report a clear usefulness for such a treatment in thyroid cancer (49). Though, for a similar expected action on NIS, RA is under consideration for the treatment of breast cancer (50).

RA can also modulate the effects of thyroid hormones on target tissues. Firstly, RA induces the expression of the thyroid hormone transporter, monocarboxylate transporter (51). This is responsible for a crosstalk between RA and thyroid hormones signalling at least during critical steps of embryo brain development (52). Secondly, although RAR and thyroid receptors do not seem to directly physically interact, they share some cofactors such as CART1 a de-repressor in the cytoplasm and NCoR2 a corepressor in the nucleus $(53,54)$. It is then likely that some form of competition occurs between the two ligands and their receptors. Subsequent consequences would then depend on resulting gene trans-activations and trans-repressions. Lastly, there are interferences between thyroid and retinoid signalling. For instance, during a vitamin A-deficient diet or in aged rats, retinoid and thyroid nuclear receptor expressions decrease. This can be corrected by either thyroid hormone or RA treatments (55). In humans, such a link is likely since a 
decreased expression of RAR occurs in mononuclear cells of hypothyroid patients (56). Conversely, an increased concentration of retinol was seen in hypothyroidism. Currently, it is not known if a thyroid hormone replacement therapy restores RA signalling back to a status seen in euthyroidism.

In conclusion, there are many levels where RA can interact with the physiology of hypothalamopituitary-thyroid axis including through vitamin A and iodine co-deficiency in low-income living conditions. Unfortunately, the hopes raised by early work in thyroid cancers are probably dashed now because of the absence of clear usefulness.

\section{Vitamin A and thyroid C cells}

No information has been reported about a role of RA and calcitonin secretion by normal thyroid C cells. In vitro, 9-cis RA decreases the release of calcitonin in the rat $\mathrm{C}$ cell line CA-77 (57), but no data are available about the spontaneous presence of 9-cis RA in C cells. atRA had no significant effect on a human medullary thyroid carcinoma cell line (58).

\section{Vitamin A and the hypothalamo-pituitary-adrenal (HPA) axis}

There are arguments for an action of RA on the HPA axis. For instance, chronic treatment of young rats by RA increases basal corticosterone concentration (59). However, most of the recent literature refers to its possible use or role in pituitary or adrenal tumours.

Firstly, RAR- $\alpha$ is co-localised with corticotrophinreleasing hormone and vasopressin in neurons of the hypothalamic paraventricular nucleus suggesting a regulation of these cells by RA $(24,25)$. Furthermore, RA is localised in some hypothalamic neurons although it is not yet known whether these neurons regulate the HPA axis (60). Retinaldehyde dehydrogenase enzymes are also localised in the hypothalamus (60). Altogether these data strongly supports a role of RA in regulating hypothalamic functions.

Secondly, RA could act on the secretion of corticotrophs, but there are apparently conflicting data. In normal rat, atRA administration increases basal serum corticosterone concentration possibly through the increased mRNA expression of corticotrophin release factor and RAR- $\alpha$ in the hypothalamus (59). No in vitro data are available about RA and normal corticotrophs.

http://www.endocrineconnections.org DOI: 10.1530/EC-17-0101
An apparently opposite effect has been shown in tumoural cells as RA reduces growth and secretion of AtT20 cells (61) possibly through bone morphogenic protein 4 action $(61,62,63,64)$. This explains recent papers about the possible use of retinoids to treat Cushing's disease (65). Ectopic ACTH secretion may also be affected by retinoids. Indeed, the nuclear co-repressor SMRT is over-expressed in ACTH-secreting thymic carcinoids suggesting that aberrant expression might be involved in the pathogenesis of tumoural cortisol resistance (66).

Thirdly, RA could possibly act on adrenals and especially on adrenal ontogeny, physiology and tumorigenesis through SMRT (67) and bone morphogenic Proteins (BMP) signalling (68). BMP are known modulators of different hormonal systems including the adrenal. On one hand, RA regulates BMP signalling by promoting the degradation of phosphorylated Smad1. On the other hand, RA promotes the transcription of GATA- 6 that in turn promotes BMP2 transcription. Whether reactivating BMP signalling in adrenocortical tumour tissues by therapeutic retinoids is yet unknown (68). Finally, a metaanalysis of adrenocortical tumour genomics data also revealed a putative role of RA signalling (69).

Lastly, part of the interaction between vitamin A and glucocorticoid action may occur downstream of adrenal hormone production as vitamin $\mathrm{A}$ and glucocorticoid receptors may interact directly or indirectly. As a consequence, RA is for instance able to decrease glucocorticoid receptor expression and modify glucocorticoid signalling in a neuronal model $(23,70,71)$. In addition, RA may modulate local glucocorticoid activation by 11 $\beta$-hydroxysteroid dehydrogenase 1 (HSD1)(72). This has been shown, in vitro in muscle cells in which RA exerts a dose-dependent downregulation of $11 \beta$-HSD1mRNA expression and activity (73). Similarly, in the liver of obese rats 11 $\beta$-HSD1 activity and gene expression are significantly reduced by vitamin A supplementation (74). Similarly, in vitamin A-deficient LOU/C rats, the expression of $11 \beta$-HSD1 is increased in the hypothalamus and the hippocampus. This increase, as well as the associated increased HPA axis activity, is normalised by RA administration (75).

\section{Vitamin A and the hypothalamo-pituitary-gonads axis}

RA is a critical factor for the formation of the gonads in man and one of the major consequences of vitamin A deficiency apart from blindness is infertility $(35,76)$. 
In Leydig as well as ovarian cells, RA stimulates steroidogenic acute regulatory protein (StAR) and P450 $17 \alpha$-hydroxylase expression and thus steroidogenesis (77). The role of RA in the production of gonadic hormones of developed gonads appears less important although RA stimulates steroid hormone synthesis.

It has been suggested that there is an interesting interplay between RA and oestrogen signalling in breast cancer cells particularly with opposite actions on cell proliferation. RAR $\alpha$ could be an integral part of the ER $\alpha$ transcriptional complex $(2,78)$. Whether this is true in normal breast cells is yet unknown and putative preventive action of breast cancer is unknown.

\section{Vitamin A and the somato-lactotroph axis}

RA probably plays a role not only in the differentiation of somatotrophs through pit-1 transcription factor (79) but also in the expression of growth hormone-releasing hormone $(\mathrm{GH}-\mathrm{RH})$ receptors in somatotrophs as there is a RARE in the promoter of GH-RH receptor gene (80). In developed somatotrophs, retinoids affect basal and $\mathrm{GH}-\mathrm{RH}$-induced $\mathrm{GH}$ secretion (80). Insulin growth factor 1 and 2 (IGF1 and IGF2) synthesis is increased by retinoids in some skin models (81) but no data are available about the most important GH-induced hepatic IGF 1 production. In pituitary tumours including somatotroph tumours, RA increases the expression of type 2 dopamine receptors; hence, a possible therapeutic use to control these tumours using routine dopaminergic drugs (82).

RA action has also been described in prolactinsecreting cells either normal or tumoural as demonstrated for corticotrophs. Again, a possible mechanism of action is the role of BMP-4, a member of the transforming growth factor $\beta$ (TGF $\beta$ ) family, overexpressed in different prolactinoma models and induces the development of these lineage adenomas (83).

\section{Vitamin A and the pancreas}

RA receptor signalling is required in early pancreatic progenitor cells for pancreatic development (84). It is also required for maintaining both beta-cell function and mass in the adult pancreas (85).

There are different lines of arguments linking endocrine $\beta$ cells function to RA. Hereafter are some of the main arguments developed in recent years $(6,86)$. Vitamin A plasma concentrations are higher in subjects with glucose intolerance and the $\mathrm{RBP} /$ retinol ratio is elevated in patients with type 2 diabetes. RA restores an insulin-secreting function of vitamin A-deprived rats. In pancreatic $\beta$ cells, atRA increases the transcription of glucokinase, glucose transporter 2 and pre-pro-insulin genes and promotes insulin secretion. Furthermore, some RXR- $\gamma$ haplotypes are associated with indicators of pancreatic $\beta$-cell function.

Conversely, 9-cisRA, the ligand of RXR receptors, decreases glucose-induced insulin secretion (87). Interestingly, the pancreas is one of the few (if any others) tissues where endogenous 9cisRA has been detected $(17,88)$. RXR agonists have been proposed to improve insulin sensitivity as 9cisRA/RXR might inhibit excessive insulin release under - only under - highglucose conditions. This action may be obtained through PPAR/RXR heterodimerisation. 13-cis RA may also be a player as it alters pancreatic cell viability (89). Furthermore, Raldh3 (retinaldehyde dehydrogenase 3 ) is present in the pancreas and promotes the formation of 13-cis RA from 13-cis retinal (90). In diabetic mice, Raldh3 expression is increased, and this is correlated with reduced insulin and increased glucagon secretions. Thus, in the pancreas, unusual RA isomers may play a role in pancreatic function, but confirmation of these studies has to be obtained.

Finally, we will not cover the very interesting topic of glucose and lipid metabolism here because many interesting studies and reviews detailed the relations of vitamin A, lipids and binding protein $(91,92,93,94,95)$.

\section{Miscellaneous}

There are in vivo and in vitro arguments in animals reporting the effects of RA on renin or angiotensin production $(96,97,98,99)$. atRA treatment increased the expression of angiotensin-converting enzyme 2 with a subsequent reduction of blood pressure in hypertensive rats. (96) To our knowledge, no clinically useful data are available neither for renin or aldosterone levels nor for the effect of RA on blood pressure.

RA seems to play neither a remarkable role in adrenal medulla organogenesis nor function in adults. In vitro, RA could initiate neuronal differentiation in PC12 cells eliciting the expression of a nerve growth factor receptor as well as tyrosine hydroxylase expression (100). This is usually considered as a differentiating action on cells sharing a common origin with neurons.

RA stimulates the erythropoietin synthesis in foetal rats via a RARE in the erythropoietin gene dependent on http://www.endocrineconnections.org DOI: 10.1530/EC-17-0101
(C) 2017 The authors Published by Bioscientifica Ltd
This work is licensed under a Creative Commons Attribution-NonCommercial-NoDerivatives 4.0 International License. 
RAR/RXR receptors $(101,102)$. In adult rats, however, this effect disappears and adult erythropoiesis takes place. The RAR/RXR complex is replaced by an orphan receptor, hepatocyte nuclear factor 4 , which binds to the same cis element to facilitate an interaction with the hypoxiainducible factor 1 bound to an adjacent site (103).

\section{Conclusion}

It is now known that vitamin A and RA and metabolites are involved in some glands development as well as functions in adults. Indeed, one of the most critical roles of vitamin A in human health is its effect on thyroid function as simultaneous iodine and vitamin A deficiencies potentiate to affect thyroid function. To achieve adequate intake of these micronutrients, among others, is indeed a challenge in developing countries. Similarly, the role of vitamin A and metabolites is certainly important in the regulation of the HPA axis although the endocrine consequences on the whole population is more difficult to assess.

Thanks to a better understanding of vitamin A and RA metabolites mechanisms of action through their various receptors some interesting pathways in normal or tumoural endocrine tissues have been uncovered. However, useful therapeutic use of agonists or antagonists of these pathways is not available yet. A use of retinoids in pituitary tumours especially corticotroph adenomas may be emerging. Well-tolerated, clinically available retinoids used for skin or hematologic diseases, renders clinical studies comparing other medical options readily possible.

\section{Declaration of interest}

The authors declare that there is no conflict of interest that could be perceived as prejudicing the impartiality of this review.

\section{Funding}

This research did not receive any specific grant from any funding agency in the public, commercial or not-for-profit sector.

\section{References}

1 Gutierrez-Mazariegos J, Theodosiou M, Campo-Paysaa F \& Schubert M. Vitamin A: a multifunctional tool for development. Seminars in Cell and Developmental Biology 201122 603-610. (doi:10.1016/j.semcdb.2011.06.001)

2 Tang XH \& Gudas LJ. Retinoids, retinoic acid receptors, and cancer. Annual Review of Pathology 20116 345-364. (doi:10.1146/annurev-pathol-011110-130303)

3 Shearer KD, Stoney PN, Morgan PJ \& McCaffery PJ. A vitamin for the brain. Trends in Neurosciences 201235 733-741. (doi:10.1016/j.tins.2012.08.005)
4 D'Ambrosio DN, Clugston RD \& Blaner WS. Vitamin A metabolism: an update. Nutrients 20113 63-103. (doi:10.3390/nu3010063)

5 Harrison EH. Mechanisms involved in the intestinal absorption of dietary vitamin A and provitamin A carotenoids. Biochimica et Biophysica Acta 20121821 70-77. (doi:10.1016/j.bbalip.2011.06.002)

6 O'Byrne SM \& Blaner WS. Retinol and retinyl esters: biochemistry and physiology. Journal of Lipid Research 201354 1731-1743. (doi:10.1194/jlr.r037648)

7 Reboul E. Absorption of vitamin A and carotenoids by the enterocyte: focus on transport proteins. Nutrients 20135 3563-3581. (doi:10.3390/nu5093563)

8 Schreiber R, Taschler U, Preiss-Landl K, Wongsiriroj N, Zimmermann $\mathrm{R} \&$ Lass A. Retinyl ester hydrolases and their roles in vitamin A homeostasis. Biochimica et Biophysica Acta 20121821 113-123. (doi:10.1016/j.bbalip.2011.05.001)

9 Allen LH \& Haskell M. Estimating the potential for vitamin A toxicity in women and young children. Journal of Nutrition 2002 132 2907S-2919S.

10 Chelstowska S, Widjaja-Adhi MA, Silvaroli JA \& Golczak M. Molecular basis for Vitamin A uptake and storage in vertebrates. Nutrients 20168 676. (doi:10.3390/nu8110676)

$11 \mathrm{Li} \mathrm{Y,} \mathrm{Wongsiriroj} \mathrm{N} \mathrm{\&} \mathrm{Blaner} \mathrm{WS.} \mathrm{The} \mathrm{multifaceted} \mathrm{nature} \mathrm{of} \mathrm{retinoid}$ transport and metabolism. Hepatobiliary Surgery and Nutrition 20143 126-139. (doi:10.3978/j.issn.2304-3881.2014.05.04)

12 Lobo GP, Hessel S, Eichinger A, Noy N, Moise AR, Wyss A, Palczewski $\mathrm{K} \&$ von Lintig J. ISX is a retinoic acid-sensitive gatekeeper that controls intestinal beta, beta-carotene absorption and vitamin A production. FASEB Journal 201024 1656-1666. (doi:10.1096/fj.09150995)

13 Kawaguchi R, Yu J, Honda J, Hu J, Whitelegge J, Ping P, Wiita P, Bok D \& Sun H. A membrane receptor for retinol binding protein mediates cellular uptake of vitamin A. Science $2007 \mathbf{3 1 5}$ 820-825. (doi:10.1126/science.1136244)

14 Slavotinek AM. Eye development genes and known syndromes. Molecular Genetics and Metabolism 2011104 448-456. (doi:10.1016/j.ymgme.2011.09.029)

15 Thatcher JE \& Isoherranen N. The role of CYP26 enzymes in retinoic acid clearance. Expert Opinion Drug Metabolism Toxicology 20095 875-886. (doi:10.1517/17425250903032681)

16 Garrido-Allepuz C, Haro E, Gonzalez-Lamuno D, Martinez-Frias ML, Bertocchini F \& Ros MA. A clinical and experimental overview of sirenomelia: insight into the mechanisms of congenital limb malformations. Disease Models and Mechanisms 20114 289-299. (doi:10.1242/dmm.007732)

17 Kane MA, Folias AE, Pingitore A, Perri M, Obrochta KM, Krois CR, Cione E, Ryu JY \& Napoli JL. Identification of 9-cisretinoic acid as a pancreas-specific autacoid that attenuates glucose-stimulated insulin secretion. PNAS 2010107 21884-21889. (doi:10.1073/pnas.1008859107)

18 Armstrong JL, Redfern CP \& Veal GJ. 13-cis retinoic acid and isomerisation in paediatric oncology - is changing shape the key to success? Biochemical Pharmacology 200569 1299-1306. (doi:10.1016/j.bcp.2005.02.003)

19 Parker RO \& Crouch RK. Retinol dehydrogenases (RDHs) in the visual cycle. Experimental Eye Research 201091 788-792. (doi:10.1016/j.exer.2010.08.013)

20 Rochette-Egly C \& Germain P. Dynamic and combinatorial control of gene expression by nuclear retinoic acid receptors (RARs). Nuclear Receptor Signaling 20097 e005. (doi:10.1621/nrs.07005)

22 Zanaria E, Muscatelli F, Bardoni B, Strom TM, Guioli S, Guo W, Lalli E, Moser C, Walker AP, McCabe ER, et al. An unusual member of the nuclear hormone receptor superfamily responsible for X-linked adrenal hypoplasia congenita. Nature 1994372 635-641. (doi:10.1038/372635a0)

21 Liu J, Zhou R, He Q, Li WI, Zhang T, Niu B, Zheng X \& Xie J. Calmodulin kinase II activation of mitogen-activated protein 
kinase in PC12 cell following all-trans retinoic acid treatment. Neurotoxicology 200930 599-604. (doi:10.1016/j.neuro.2009.03.006)

23 Brossaud J, Roumes H, Helbling JC, Moisan MP, Pallet V, Ferreira G, Biyong EF, Redonnet A \& Corcuff JB. Retinoic acid increases glucocorticoid receptor phosphorylation via cyclindependent kinase 5. Molecular and Cellular Neuroscience 201782 96-104. (doi:10.1016/j.mcn.2017.05.001)

24 Chen XN, Meng QY, Bao AM, Swaab DF, Wang GH \& Zhou JN. The involvement of retinoic acid receptor-alpha in corticotropinreleasing hormone gene expression and affective disorders. Biological Psychiatry 200966 832-839. (doi:10.1016/j.biopsych.2009.05.031)

25 Meng QY, Chen XN, Zhao J, Swaab DF \& Zhou JN. Distribution of retinoic acid receptor-alpha immunoreactivity in the human hypothalamus. Neuroscience 2011174 132-142. (doi:10.1016/j.neuroscience.2010.11.058)

26 Nogami H, Matsubara M, Harigaya T, Katayama M \& Kawamura $\mathrm{K}$. Retinoic acids and thyroid hormone act synergistically with dexamethasone to increase growth hormone-releasing hormone receptor messenger ribonucleic acid expression. Endocrinology 2000 141 4396-4401. (doi:10.1210/endo.141.12.7838)

27 Nogami H, Hiraoka Y, Matsubara M, Nonobe E, Harigaya T, Katayama M, Hemmi N, Kobayashi S, Mogi K, Aiso S, et al. A composite hormone response element regulates transcription of the rat GHRH receptor gene. Endocrinology 2002143 1318-1326. (doi:10.1210/endo.143.4.8710)

28 Fujiwara K, Kikuchi M, Horiguchi K, Kusumoto K, Kouki T, Kawanishi $\mathrm{K} \&$ Yashiro T. Estrogen receptor alpha regulates retinaldehyde dehydrogenase 1 expression in rat anterior pituitary cells. Endocrine Journal 200956 963-973. (doi:10.1507/endocrj.K09E-115)

29 Muhlbauer M, da Silva AC, Marassi MP, Lourenco AL, Ferreira AC \& de Carvalho DP. Retinoic acid modulation of thyroid dual oxidase activity in rats and its impact on thyroid iodine organification. Journal of Endocrinology 2010205 271-277. (doi:10.1677/JOE-09-0421)

30 Fujiwara K, Kikuchi M, Takigami S, Kouki T \& Yashiro T. Expression of retinaldehyde dehydrogenase 1 in the anterior pituitary glands of adult rats. Cell and Tissue Research 2007329 321-327. (doi:10.1007/s00441-007-0423-5)

31 Zimmermann MB. Interactions of vitamin A and iodine deficiencies: effects on the pituitary-thyroid axis. International Journal for Vitamin and Nutrition Research $2007 \mathbf{7 7}$ 236-240. (doi:10.1024/0300-9831.77.3.236)

32 Zimmermann MB, Jooste PL, Mabapa NS, Schoeman S, Biebinger $\mathrm{R}$, Mushaphi LF \& MbhenyaneX. Vitamin A supplementation in iodine-deficient African children decreases thyrotropin stimulation of the thyroid and reduces the goiter rate. American Journal of Clinical Nutrition 200786 1040-1044.

33 Hess SY. The impact of common micronutrient deficiencies on iodine and thyroid metabolism: the evidence from human studies. Best Practice and Research 201024 117-132. (doi:10.1016/j.beem.2009.08.012)

34 Haider SG. Cell biology of Leydig cells in the testis. International Review of Cytology 2004233 181-241. (doi:10.1016/ s0074-7696(04)33005-6)

35 Clagett-Dame M \& Knutson D. Vitamin A in reproduction and development. Nutrients 20113 385-428. (doi:10.3390/nu3040385)

36 Angioni AR, Lania A, Cattaneo A, Beck-Peccoz P \& Spada A. Effects of chronic retinoid administration on pituitary function. Journal of Endocrinological Investigation 200528 961-964. (doi:10.1007/BF03345332)

37 De Felice M \& Di Lauro R. Minireview: intrinsic and extrinsic factors in thyroid gland development: an update. Endocrinology 2011152 2948-2956. (doi:10.1210/en.2011-0204)

38 Zimmermann MB, Wegmuller R, Zeder C, Chaouki N \& Torresani $\mathrm{T}$. The effects of vitamin A deficiency and vitamin A supplementation on thyroid function in goitrous children.
Journal of Clinical Endocrinology and Metabolism 200489 5441-5447. (doi:10.1210/jc.2004-0862)

39 Morley JE, Melmed S, Reed A, Kasson BG, Levin SR, Pekary AE \& Hershman JM. Effect of vitamin A on the hypothalamo-pituitarythyroid axis. American Journal of Physiology 1980238 E174-E179.

40 Tuncel M, Aydin D, Yaman E, Tazebay UH, Guc D, Dogan AL, Tasbasan B \& Ugur O. The comparative effects of gene modulators on thyroid-specific genes and radioiodine uptake. Cancer Biotherapy and Radiopharmaceuticals 200722 443-449. (doi:10.1089/cbr.2006.319.A)

41 Namba H, Yamashita S, Morita S, Villadolid MC, Kimura H, Yokoyama N, Izumi M, Ishikawa N, Ito K \& Nagataki S. Retinoic acid inhibits human thyroid peroxidase and thyroglobulin gene expression in cultured human thyrocytes. Journal of Endocrinological Investigation 199316 87-93. (doi:10.1007/BF03347654)

42 del Senno L, Rossi R, Franceschetti P \& degli Uberti EC. Expression of all-trans-retinoic acid receptor RNA in human thyroid cells. Biochemistry and Molecular Biology International 199433 1107-1115.

43 Schmutzler C, Winzer R, Meissner-Weigl J \& Kohrle J. Retinoic acid increases sodium/iodide symporter mRNA levels in human thyroid cancer cell lines and suppresses expression of functional symporter in nontransformed FRTL-5 rat thyroid cells. Biochemical and Biophysical Research Communications 1997240 832-838. (doi:10.1006/bbrc.1997.7715)

44 Kogai T, Taki K \& Brent GA. Enhancement of sodium/iodide symporter expression in thyroid and breast cancer. Endocrine-Related Cancer 200613 797-826. (doi:10.1677/erc.1.01143)

45 Grunwald F, Pakos E, Bender H, Menzel C, Otte R, Palmedo H, Pfeifer U \& Biersack HJ. Redifferentiation therapy with retinoic acid in follicular thyroid cancer. Journal of Nuclear Medicine 1998 39 1555-1558.

46 Simon D, Koehrle J, Reiners C, Boerner AR, Schmutzler C, Mainz K, Goretzki PE \& Roeher HD. Redifferentiation therapy with retinoids: therapeutic option for advanced follicular and papillary thyroid carcinoma. World Journal of Surgery 199822 569-574. (doi:10.1007/s002689900436)

47 Coelho SM, Vaisman M \& Carvalho DP. Tumour re-differentiation effect of retinoic acid: a novel therapeutic approach for advanced thyroid cancer. Current Pharmaceutical Design 200511 2525-2531. (doi:10.2174/1381612054367490)

48 Schmutzler C \& Koehrle J. Innovative strategies for the treatment of thyroid cancer. European Journal of Endocrinology 2000143 15-24. (doi:10.1530/eje.0.1430015)

49 O'Neill CJ, Oucharek J, Learoyd D \& Sidhu SB. Standard and emerging therapies for metastatic differentiated thyroid cancer. Oncologist 201015 146-156. (doi:10.1634/theoncologist.2009-0190)

50 Kogai T \& Brent GA. The sodium iodide symporter (NIS): regulation and approaches to targeting for cancer therapeutics. Pharmacology and Therapeutics 2012135 355-370. (doi:10.1016/j.pharmthera.2012.06.007)

51 Kogai T, Liu YY, Richter LL, Mody K, Kagechika H \& Brent GA. Retinoic acid induces expression of the thyroid hormone transporter, monocarboxylate transporter 8 (Mct8). Journal of Biological Chemistry 2010285 27279-27288. (doi:10.1074/jbc.M110.123158)

52 Bernal J. Thyroid hormone transport in developing brain. Current Opinion in Endocrinology, Diabetes and Obesity 201118 295-299. (doi:10.1097/MED.0b013e32834a78b3)

53 Park UH, Kim EJ \& Um SJ. A novel cytoplasmic adaptor for retinoic acid receptor (RAR) and thyroid receptor functions as a Derepressor of RAR in the absence of retinoic acid. Journal of Biological Chemistry 2010285 34269-34278. (doi:10.1074/jbc.M110.143008)

54 Chen JD \& Evans RM. A transcriptional co-repressor that interacts with nuclear hormone receptors. Nature 1995377 454-457. (doi:10.1038/377454a0)

55 Feart C, Vallortigara J, Higueret D, Gatta B, Tabarin A, Enderlin V, Higueret P \& Pallet V. Decreased expression of retinoid nuclear receptor (RAR alpha and RAR gamma) mRNA determined by

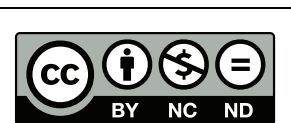

This work is licensed under a Creative Commons Attribution-NonCommercial-NoDerivatives 4.0 International License. 
real-time quantitative RT-PCR in peripheral blood mononuclear cells of hypothyroid patients. Journal of Molecular Endocrinology 200534 849-858. (doi:10.1677/jme.1.01662)

56 Feart C, Pallet V, Boucheron C, Higueret D, Alfos S, Letenneur L, Dartigues JF \& Higueret P. Aging affects the retinoic acid and the triiodothyronine nuclear receptor mRNA expression in human peripheral blood mononuclear cells. European Journal of Endocrinology 2005152 449-458. (doi:10.1530/eje.1.01858)

57 Lamari Y \& Garel JM. Decrease in CGRP and CT levels either contained in or released by CA-77 C cells after combined treatments with 1,25-dihydroxyvitamin D3 analogues and 9-cis retinoic acid. Reproduction Nutrition Development 199737 3-12. (doi:10.1051/rnd:19970101)

58 Elisei R, Vivaldi A, Agate L, Ciampi R, Molinaro E, Piampiani P, Romei C, Faviana P, Basolo F, Miccoli P, et al. All-trans-retinoic acid treatment inhibits the growth of retinoic acid receptor beta messenger ribonucleic acid expressing thyroid cancer cell lines but does not reinduce the expression of thyroid-specific genes. Journal of Clinical Endocrinology and Metabolism 200590 2403-2411. (doi:10.1210/jc.2004-0969)

59 Cai L, Yan XB, Chen XN, Meng QY \& Zhou JN. Chronic all-trans retinoic acid administration induced hyperactivity of HPA axis and behavioral changes in young rats. European Neuropsychopharmacology 201020 839-847. (doi:10.1016/j.euroneuro.2010.06.019)

60 Mangas A, Bodet D, Duleu S, Yajeya J, Geffard M \& Covenas R. Direct visualization of retinoic acid in the rat hypothalamus: an immunohistochemical study. Neuroscience Letters $2012 \mathbf{5 0 9}$ 64-68. (doi:10.1016/j.neulet.2011.12.053)

61 Paez-Pereda M, Kovalovsky D, Hopfner U, Theodoropoulou M, Pagotto U, Uhl E, Losa M, Stalla J, Grubler Y, Missale C, et al. Retinoic acid prevents experimental Cushing syndrome. Journal of Clinical Investigation 2001108 1123-1131. (doi:10.1172/JCI11098)

62 Giacomini D, Paez-Pereda M, Theodoropoulou M, Labeur M, Refojo D, Gerez J, Chervin A, Berner S, Losa M, Buchfelder M, et al. Bone morphogenetic protein-4 inhibits corticotroph tumor cells: involvement in the retinoic acid inhibitory action. Endocrinology 2006147 247-256. (doi:10.1210/en.2005-0958)

63 Labeur M, Paez-Pereda M, Haedo M, Arzt E \& Stalla GK. Pituitary tumors: cell type-specific roles for BMP-4. Molecular and Cellular Endocrinology 2010326 85-88. (doi:10.1016/j.mce.2010.04.006)

64 Yacqub-Usman K, Duong CV, Clayton RN \& Farrell WE. Preincubation of pituitary tumor cells with the epidrugs zebularine and trichostatin A are permissive for retinoic acid-augmented expression of the BMP-4 and D2R genes. Endocrinology $2013 \mathbf{1 5 4}$ 1711-1721. (doi:10.1210/en.2013-1061)

65 Pecori Giraldi F, Ambrogio AG, Andrioli M, Sanguin F, Karamouzis I, Corsello SM, Scaroni C, Arvat E, Pontecorvi A \& Cavagnini F. Potential role for retinoic acid in patients with Cushing's disease. Journal of Clinical Endocrinology and Metabolism 201297 3577-3583. (doi:10.1210/jc.2012-2328)

66 Jiang J, Li N, Wang X, Lu Y, Bi Y, Wang W, Li X \& Ning G. Aberrant expression and modification of silencing mediator of retinoic acid and thyroid hormone receptors involved in the pathogenesis of tumoral cortisol resistance. Endocrinology 2010151 3697-3705. (doi:10.1210/en.2010-0335)

67 Clipsham R \& McCabe ER. DAX1 and its network partners: exploring complexity in development. Molecular Genetics and Metabolism 2003 80 81-120. (doi:10.1016/j.ymgme.2003.08.023)

68 Johnsen IK \& Beuschlein F. Role of bone morphogenetic proteins in adrenal physiology and disease. Journal of Molecular Endocrinology 201044 203-211. (doi:10.1677/JME-10-0001)

69 Szabo PM, Tamasi V, Molnar V, Andrasfalvy M, Tombol Z, Farkas R, Kovesdi K, Patocs A, Toth M, Szalai C, et al. Meta-analysis of adrenocortical tumour genomics data: novel pathogenic pathways revealed. Oncogene 201029 3163-3172. (doi:10.1038/onc.2010.80)
70 Brossaud J, Roumes H, Moisan MP, Pallet V, Redonnet A \& Corcuff JB. Retinoids and glucocorticoids target common genes in hippocampal HT22 cells. Journal of Neurochemistry $2013 \mathbf{1 2 5}$ 518-531. (doi:10.1111/jnc.12192)

71 Roumes H, Brossaud J, Lemelletier A, Moisan M, Pallet V, Redonnet A \& Corcuff J. Retinoids and glucocorticoids have opposite effects on actin cytoskeleton rearrangement in hippocampal HT22 cells. International Journal of Biochemistry and Cell Biology 201671 102-110. (doi:10.1016/j.biocel.2015.12.014)

72 Bonhomme D, Minni AM, Alfos S, Roux P, Richard E, Higueret P, Moisan MP, Pallet V \& Touyarot K. Vitamin A status regulates glucocorticoid availability in Wistar rats: consequences on cognitive functions and hippocampal neurogenesis? Frontiers in Behavioral Neuroscience 20148 20. (doi:10.3389/fnbeh.2014.00020)

73 Aubry EM \& Odermatt A. Retinoic acid reduces glucocorticoid sensitivity in C2C12 myotubes by decreasing 11beta-hydroxysteroid dehydrogenase type 1 and glucocorticoid receptor activities. Endocrinology 2009150 2700-2708. (doi:10.1210/en.2008-1618)

74 Sakamuri VP, Ananthathmakula P, Veettil GN \& Ayyalasomayajula V. Vitamin A decreases pre-receptor amplification of glucocorticoids in obesity: study on the effect of vitamin A on 11betahydroxysteroid dehydrogenase type 1 activity in liver and visceral fat of WNIN/Ob obese rats. Nutrition Journal $2011 \mathbf{1 0}$ 70. (doi:10.1186/1475-2891-10-70)

75 Marissal-Arvy N, Hamiani R, Richard E, Moisan MP \& Pallet V. Vitamin A regulates hypothalamic-pituitary-adrenal axis status in LOU/C rats. Journal of Endocrinology 2013219 21-27. (doi:10.1530/JOE-13-0062)

76 Livera G, Rouiller-Fabre V, Pairault C, Levacher C \& Habert R. Regulation and perturbation of testicular functions by vitamin $\mathrm{A}$. Reproduction 2002124 173-180. (doi:10.1530/rep.0.1240173)

77 Wickenheisser JK, Nelson-DeGrave VL, Hendricks KL, Legro RS, Strauss JF 3rd \& McAllister JM. Retinoids and retinol differentially regulate steroid biosynthesis in ovarian theca cells isolated from normal cycling women and women with polycystic ovary syndrome. Journal of Clinical Endocrinology and Metabolism 200590 4858-4865. (doi:10.1210/jc.2005-0330)

78 Ombra MN, Di Santi A, Abbondanza C, Migliaccio A, Avvedimento EV \& Perillo B. Retinoic acid impairs estrogen signaling in breast cancer cells by interfering with activation of LSD1 via PKA. Biochimica et Biophysica Acta 20131829 480-486. (doi:10.1016/j.bbagrm.2013.03.003)

79 Cheng Y, Xiang Y, Lin Y, Fu S, Jia W, Zhang G, Lv W, Mi S \& Zhao Q. Retinoic acid and dexamethasone induce differentiation and maturation of somatotroph cells at different stages in vitro. Endocrine Journal 201158 177-184. (doi:10.1507/endocrj.K10E-315)

80 Mallo F, Lamas JA, Casanueva FF \& Dieguez C. Effect of retinoic acid deficiency on in vivo and in vitro GH responses to GHRH in male rats. Neuroendocrinology $1992 \mathbf{5 5}$ 642-647. (doi:10.1159/000126183)

81 Shim JH, Shin DW, Lee TR, Kang HH, Jin SH \& Noh M. The retinoic acid-induced up-regulation of insulin-like growth factor 1 and 2 is associated with prolidase-dependent collagen synthesis in UVAirradiated human dermal equivalents. Journal of Dermatological Science 201266 51-59. (doi:10.1016/j.jdermsci.2011.12.008)

82 Bondioni S, Angioni AR, Corbetta S, Locatelli M, Ferrero S, Ferrante E, Mantovani G, Olgiati L, Beck-Peccoz P, Spada A, et al. Effect of 9-cis retinoic acid on dopamine $\mathrm{D} 2$ receptor expression in pituitary adenoma cells. Experimental Biology and Medicine 2008233 439-446. (doi:10.3181/0704-RM-94)

83 Giacomini D, Paez-Pereda M, Theodoropoulou M, Gerez J, Nagashima AC, Chervin A, Berner S, Labeur M, Refojo D, Renner $\mathrm{U}$, et al. Bone morphogenetic protein- 4 control of pituitary pathophysiology. Frontiers of Hormone Research 2006 35 22-31.(doi:10.1159/000094262) 
84 Kam RK, Deng Y, Chen Y \& Zhao H. Retinoic acid synthesis and functions in early embryonic development. Cell and Bioscience 2012 2 11. (doi:10.1186/2045-3701-2-11)

85 Brun PJ, Grijalva A, Rausch R, Watson E, Yuen JJ, Das BC, Shudo K, Kagechika H, Leibel RL \& Blaner WS. Retinoic acid receptor signaling is required to maintain glucose-stimulated insulin secretion and beta-cell mass. FASEB Journal 201529 671-683. (doi:10.1096/fj.14-256743)

86 Yang Q, Graham TE, Mody N, Preitner F, Peroni OD, Zabolotny JM, Kotani K, Quadro L \& Kahn BB. Serum retinol binding protein 4 contributes to insulin resistance in obesity and type 2 diabetes. Nature 2005436 356-362. (doi:10.1038/nature03711)

87 Miyazaki S, Taniguchi H, Moritoh Y, Tashiro F, Yamamoto T, Yamato E, Ikegami H, Ozato K \& Miyazaki J. Nuclear hormone retinoid $X$ receptor (RXR) negatively regulates the glucosestimulated insulin secretion of pancreatic ss-cells. Diabetes 201059 2854-2861. (doi:10.2337/db09-1897)

88 Kane MA. Analysis, occurrence, and function of 9-cisretinoic acid. Biochimica et Biophysica Acta 20121821 10-20. (doi:10.1016/j.bbalip.2011.09.012)

89 Shimamura M, Karasawa H, Sakakibara S \& Shinagawa A. Raldh3 expression in diabetic islets reciprocally regulates secretion of insulin and glucagon from pancreatic islets. Biochemical and Biophysical Research Communications 2010401 79-84. (doi:10.1016/j.bbrc.2010.09.013)

90 Graham CE, Brocklehurst K, Pickersgill RW \& Warren MJ. Characterization of retinaldehyde dehydrogenase 3. Biochemical Journal 2006394 67-75. (doi:10.1042/BJ20050918)

91 Yasmeen R, Jeyakumar SM, Reichert B, Yang F \& Ziouzenkova $\mathrm{O}$. The contribution of vitamin A to autocrine regulation of fat depots. Biochimica et Biophysica Acta 20121821 190-197. (doi:10.1016/j.bbalip.2011.06.004)

92 Bonet ML, Ribot J \& Palou A. Lipid metabolism in mammalian tissues and its control by retinoic acid. Biochimica et Biophysica Acta 20121821 177-189. (doi:10.1016/j.bbalip.2011.06.001)

93 Berry DC \& Noy N. All-trans-retinoic acid represses obesity and insulin resistance by activating both peroxisome proliferationactivated receptor beta/delta and retinoic acid receptor. Molecular and Cellular Biology 200929 3286-3296. (doi:10.1128/MCB.01742-08)

94 Cadoudal T, Glorian M, Massias A, Fouque F, Forest C \& Benelli C. Retinoids upregulate phosphoenolpyruvate carboxykinase and glyceroneogenesis in human and rodent adipocytes. Journal of Nutrition 2008138 1004-1009.

95 Iacobazzi V, Convertini P, Infantino V, Scarcia P, Todisco S \& Palmieri F. Statins, fibrates and retinoic acid upregulate mitochondrial acylcarnitine carrier gene expression. Biochemical and Biophysical Research Communications 2009388 643-647. (doi:10.1016/j.bbrc.2009.08.008)

96 Zhong JC, Huang DY, Yang YM, Li YF, Liu GF, Song XH \& Du K. Upregulation of angiotensin-converting enzyme 2 by all-trans retinoic acid in spontaneously hypertensive rats. Hypertension 2004 44 907-912. (doi:10.1161/01.HYP.0000146400.57221.74)

97 Guleria RS, Choudhary R, Tanaka T, Baker KM \& Pan J. Retinoic acid receptor-mediated signaling protects cardiomyocytes from hyperglycemia induced apoptosis: role of the reninangiotensin system. Journal of Cellular Physiology 2011226 1292-1307. (doi:10.1002/jcp.22457)

98 Zhou TB, Wu WF, Qin YH \& Yin SS. Association of alltrans retinoic acid treatment with the renin-angiotensin aldosterone system expression in glomerulosclerosis rats. Journal of the Renin-Angiotensin-Aldosterone System 201314 299-307. (doi:10.1177/1470320312465220)

99 Glenn ST, Jones CA, Gross KW \& Pan L. Control of renin (corrected) gene expression. Pflugers Archiv 2013465 13-21. (doi:10.1007/s00424-012-1110-2)

100 Cosgaya JM, Garcia-Villalba P, Perona R \& Aranda A. Comparison of the effects of retinoic acid and nerve growth factor on PC12 cell proliferation, differentiation, and gene expression. Journal of Neurochemistry $1996 \mathbf{6 6}$ 89-98. (doi:10.1046/j.1471-4159.1996.66010089.x)

101 Brade T, Kumar S, Cunningham TJ, Chatzi C, Zhao X, Cavallero S, Li P, Sucov HM, Ruiz-Lozano P \& Duester G. Retinoic acid stimulates myocardial expansion by induction of hepatic erythropoietin which activates epicardial Igf2. Development 2011138 139-148. (doi:10.1242/dev.054239)

102 Makita T, Duncan SA \& Sucov HM. Retinoic acid, hypoxia, and GATA factors cooperatively control the onset of fetal liver erythropoietin expression and erythropoietic differentiation. Developmental Biology 2005280 59-72. (doi:10.1016/j.ydbio.2005.01.001)

103 Evans T. Regulation of hematopoiesis by retinoid signaling. Experimental Hematology 200533 1055-1061. (doi:10.1016/j.exphem.2005.06.007)

Received in final form 3 July 2017

Accepted 18 July 2017

Accepted Preprint published online 18 July 2017 http://www.endocrineconnections.org DOI: 10.1530/EC-17-0101
(C) 2017 The authors Published by Bioscientifica Ltd
This work is licensed under a Creative Commons Attribution-NonCommercial-NoDerivatives 4.0 International License. 